\title{
Phylogeny, systematics and biogeography of the European sand gobies (Gobiiformes: Gobionellidae)
}

\section{CHRISTINE E. THACKER ${ }^{1 *}$, CHRISTOS GKENAS ${ }^{2,3}$, ALEXANDROS TRIANTAFYLLIDIS ${ }^{4}$, STEFANO MALAVASI ${ }^{5}$ AND IOANNIS LEONARDOS ${ }^{3}$}

\author{
${ }^{1}$ Research and Collections, Section of Ichthyology, Natural History Museum of Los Angeles County, 900 \\ Exposition Boulevard, Los Angeles, CA 90007, USA \\ ${ }^{2}$ MARE, Centro de Ciências do Mar e do Ambiente, Faculdade de Ciências, Universidade de Lisboa, \\ 1749-016 Lisboa, Portugal \\ ${ }^{3}$ Laboratory of Zoology, Department of Biological Applications and Technology, University of Ioannina, \\ 45110 Ioannina, Greece \\ ${ }^{4}$ Department of Genetics, Development, and Molecular Biology, School of Biology, Aristotle University of \\ Thessaloniki, 54124 Thessaloniki, Greece \\ ${ }^{5}$ Department of Environmental Sciences, Informatics, and Statistics, Ca' Foscari University Venice, via \\ Torino 155-30172 Venice, Italy
}

Received 10 January 2018; revised 6 March 2018; accepted for publication 19 March 2018

\begin{abstract}
The sand gobies are a group of 30 species in five genera (Knipowitschia, Pomatoschistus, Economidichthys, Ninnigobius and Orsinigobius) native to the seas and fresh waters of Europe and the Ponto-Caspian region. We construct a phylogeny incorporating new DNA sequence data (mitochondrial COI gene) for species in Greece and the Adriatic (Venetian Lagoon) with existing sequences sampled from throughout European waters. Our comprehensive analysis confirms the distinctness of Orsinigobius and Ninnigobius, supports that Gobiusculus is part of Pomatoschistus and supports the monophyly of Economidichthys and Knipowitschia. We then calibrate the phylogeny using fossils, interpret the phylogenetic biogeography of sand gobies throughout Europe and the Mediterranean and estimate the historical divergence patterns in the group. We infer the origin of the sand goby clade at 33.0 Mya, near the Eocene-Oligocene boundary, and show that radiations among marine Pomatoschistus clades in the Miocene are correlated with the closure of the Tethys seaway. Younger freshwater clades of Ninnigobius, Orsinigobius and subclades of Knipowitschia diversified in the late Miocene and early Pliocene, centred in the Adriatic region and concordant with the Lago Mare phase of the Messinian salinity crisis. Economidichthys is the exception to this pattern; it inhabits freshwater but originated and diversified during the mid-Miocene.
\end{abstract}

ADDITIONAL KEYWORDS: DNA barcode, Economidichthys - Europe - Gobiidae - Gobiusculus - Knipowitschia - Lago Mare, Mediterranean - Orsinigobius - Pomatoschistus - Tethys.

\section{INTRODUCTION}

The seas and freshwaters of Europe host a diverse and complex goby fauna, including wide-ranging marine and euryhaline species in addition to geographically restricted freshwater endemics. They are familiar and well known, and include several species of conservation concern (Miller, 1990, 2004; Vanhove et al., 2012). Among the European species are a group of five genera

*Corresponding author. E-mail: thacker@nhm.org collectively known as sand gobies (Knipowitschia Iljin, 1927; Pomatoschistus Gill, 1863; Economidichthys Bianco, Bullock, Miller \& Roubal, 1987; the genera Ninnigobius Whitley, 1951 and Orsinigobius Gandolfi, Marconato \& Torricelli, 1986 have also been used). Together, those genera contain 30 species and are distributed from the coastal Atlantic of western Europe, throughout the Mediterranean and many of its associated freshwaters, and into the drainages of the Black, Aral and Caspian seas. Taxonomic and phylogenetic work on the group has been extensive and sometimes contradictory but has yielded a wealth of data bearing 
on relationships both within sand goby genera and among sand gobies and their more distant relatives (Penzo et al., 1988; Huyse, Van Houdt \& Volckaert, 2004; Larmuseau et al., 2010; Malavasi et al., 2012; Vanhove et al., 2012).

Sand gobies are well supported as a monophyletic group, based on both molecular and morphological data [mitochondrial 12S/16S: Penzo et al., 1988; Huyse et al., 2004; Larmuseau et al., 2010 (also rhodopsin); Vanhove et al., 2012; morphology: Economidis \& Miller, 1990; Malavasi et al., 2012). The placement of sand gobies within Gobioidei has been more obscure, but the higher level works of Thacker \& Roje (2011), Thacker (2011, 2013) and, in particular, Agorreta et al. (2013) have shown that sand gobies are part of the family Gobionellidae, sister to European marine genera such as Buenia Iljin, 1930, Deltentosteus Gill, 1863 and Lebetus Winther, 1877, rather than the more distantly related Gobius Linnaeus, 1758, Padogobius Iljin, 1933, Zebrus (deBuen, 1930) and Zosterisessor Whitley, 1935 in the family Gobiidae (complete generic composition of gobiid and gobionellid lineages is given by Thacker, 2015). This placement explains the observation in earlier phylogenetic studies that sand gobies are deeply divided from common European marine gobies, as noted by McKay \& Miller (1997) and Penzo et al. (1998) and as depicted in the phylogenies of Huyse et al. (2004), Larmuseau et al. (2010) and Vanhove et al. (2012).

Among sand gobies, the two largest genera (Knipowitschia and Pomatoschistus) are distinct, both in ecology and in distribution. Pomatoschistus species inhabit marine or occasionally estuarine waters and are distributed along the coasts of the Baltic, northeastern Atlantic, Mediterranean and Adriatic seas. They are found in inshore mud, sand or rubble habitats (Miller, 1986). Knipowitschia prefers estuarine to fresh waters. It is known from the streams and coastal lagoons of the Adriatic, but from there its distribution stretches to the east, including the eastern Mediterranean, the Aegean and the shores of the Black, Caspian and Aral seas. A few Knipowitschia are landlocked freshwater endemics with very restricted ranges (Ahnelt, 2011; Vukić et al., 2016). Economidichthys is a genus of two species that is known only from coastal lakes and rivers in western Greece (Miller, 2004; Kottelat \& Freyhof, 2007; Freyhof, 2011).

Phylogenetic studies focusing on sand gobies have varied in their sampling and in the details of their recovered relationships, but all have shown that Knipowitschia and Pomatoschistus are not monophyletic as traditionally construed. Much of the nonmonophyly is alleviated if two smaller genera, Orsinigobius and Ninnigobius, are recognized. Orsinigobius [including species Orsinigobius punctatissimus (Canestrinii, 1864) and Orsinigobius croaticus (Mrakovčić, Kerovec,
Misetic \& Schneider, 1996)] and Ninnigobius [including Ninnigobius canestrinii (Ninni,1883) and Ninnigobius montenegrensis (Miller \& Šanda, 2008)] are distinct from Knipowitschia and Pomatoschistus, respectively (Ahnelt \& Bianco, 1990; Huyse et al., 2004; Miller \& Šanda, 2008; Vanhove et al., 2012; Geiger et al., 2014). There is also agreement across several molecular phylogenetic analyses that Gobiusculus flavescens Fabricius, 1779, a common species in coastal marine habitats from the Atlantic coast of Spain northward into Norway, is nested within Pomatoschistus (Huyse et al., 2004; Larmuseau et al., 2010; Vanhove et al., 2012; Knebelsberger \& Thiel, 2014). Within Pomatoschistus and Knipowitschia, interrelationships of some species have been investigated (Geiger et al., 2014; Knebelsberger \& Thiel, 2014; Vukić et al., 2016), but there has not been a comprehensive phylogenetic hypothesis inferred among and within sand goby genera.

Significant sources of inter- and intraspecific sequence information for sand gobies are the various recent efforts to obtain DNA barcodes for European fishes. The studies of Costa et al. (2012), Geiger et al. (2014), Knebelsberger \& Thiel (2014) and Landi et al. (2014) have generated abundant data for the mitochondrial $C O I$ locus and demonstrated its usefulness in species identification and application of conservation. Those data are also suitable for phylogenetic analysis and are among the most reliable mitochondrial genes for that purpose (Zardoya \& Meyer, 1996). Although the $C O I$ locus generally does not provide sufficient phylogenetic resolution for large-scale analyses (Rubinoff \& Holland, 2005), here the taxonomic scope is narrow enough that $C O I$ is useful. In the present study, we combine existing $C O I$ data with new sequences for several species of sand gobies sampled from around mainland Greece and the Adriatic (Venetian Lagoon). We use this combined data set to infer a comprehensive sand goby phylogeny and evaluate how well current generic and species assignments concur with phylogenetic patterns. We then use the fossil record of sand gobies, along with a legacy calibration for Gobionellidae, to calibrate the phylogeny, and we consider the ages and biogeographical patterns of various sand goby radiations in the context of the geological history of Europe.

\section{MATERIAL AND METHODS}

\section{SPECIMEN COLLECTION AND DNA EXTRACTION, AMPLIFICATION AND SEQUENCING}

We collected 71 specimens either by hand net or by electrofishing gear from 18 geographically distinct localities throughout the sand gobies' distributional range in Greece. To expand the sample size and geographical 
breadth, we also included 12 samples from three species from the Venetian Lagoon in the analysis (Table 1, Fig. 1). The specimens were killed by immersion in tricaine methanesulphonate (MS-222), placed on ice, and fixed later in the laboratory in 70-100\% ethanol. Information on sample codes, species and sampling localities is given in Table 1, and a map of localities is shown in Figure 1.

We extracted total genomic DNA from muscle tissues by standard sodium dodecyl sulphate proteinase-K digestion, phenol:chloroform:isoamyalcohol extraction and ethanol precipitation. We amplified a partial segment of the mitochondrial protein encoding the COI gene using the forward primer FishF1 5'-TCAACCAACCACAAAGACATTGGCAC-3' and the reverse primer FishR1 5'-TAGACTTCTGGGTGG CCAAAGAATCA-3' (Ward et al., 2005). An alternative primer pair, FishF2 5'-TCGACTAATCAT AAAGATATCGGCAC-3' and FishR2 5'-ACTTCA GGGTGACCGAAGAATCAGAA-3', was used (Ward et al., 2005) for $N$. canestrinii. We performed PCR amplifications in a final volume of $25 \mu \mathrm{L}$ containing template DNA (10-100 ng), $25 \mathrm{mM} \mathrm{MgCl}, 0.4 \mu \mathrm{M}$ of each primer and Taq DNA polymerase (Qiagen Inc.). The cycling profile of the PCR included an initial denaturation of $95{ }^{\circ} \mathrm{C}$ for $2 \mathrm{~min}, 35$ cycles of $94{ }^{\circ} \mathrm{C}$ for $30 \mathrm{~s}$, $53^{\circ} \mathrm{C}$ for $30 \mathrm{~s}$ and $72^{\circ} \mathrm{C}$ for $60 \mathrm{~s}$, with a final extension of $92^{\circ} \mathrm{C}$ for $10 \mathrm{~min}$. The PCRs were checked on $2 \%$ agarose gels stained with ethidium bromide, and excess

Table 1. List of the species examined from each sampling area, categorized by region

\begin{tabular}{|c|c|c|c|}
\hline Site & Locality & Species & GenBank number \\
\hline \multicolumn{4}{|c|}{ Aegean coast } \\
\hline 1 & Drana Lagoon & Knipowitschia caucasica & KX673961-63 \\
\hline 2 & Lake Vistonis & Knipowitschia caucasica & KX673957-60 \\
\hline \multirow[t]{2}{*}{3} & Vassova Lagoon & Knipowitschia caucasica & KX673953-56 \\
\hline & & Pomatoschistus marmoratus & KX673972 \\
\hline 4 & Rihios River & Knipowitschia caucasica & KX673948-49 \\
\hline 5 & Lake Volvi & Knipowitschia caucasica & KX673950-52 \\
\hline 6 & Axios River & Knipowitschia caucasica & KX673944-47 \\
\hline \multicolumn{4}{|c|}{ Thessaly } \\
\hline 7 & Lake Karla & Knipowitschia thessala & KX673940-43 \\
\hline \multicolumn{4}{|c|}{ Ionian coast } \\
\hline 8 & Lake Kaiafa & Knipowitschia milleri & KX673937-39 \\
\hline 9 & Kotyhi Lagoon & Knipowitschia milleri & KX673932-36 \\
\hline 10 & Kalogria Lagoon & Knipowitschia milleri & KX673926-31 \\
\hline \multirow[t]{2}{*}{11} & Trichonis Lake & Economidichthys trichonis & KX673893 \\
\hline & & Economidichthys pygmaeus & KX673908-12 \\
\hline 12 & Agios Dimitrios River & Economidichthys pygmaeus & KX673913-15 \\
\hline 13 & Louros River & Economidichthys pygmaeus & KX673902-04 \\
\hline 14 & Arachthos River & Economidichthys pygmaeus & KX673897 \\
\hline 15 & Ziros Lake & Economidichthys pygmaeus & KX673898-01 \\
\hline \multirow[t]{2}{*}{16} & Pamvotis Lake & Economidichthys pygmaeus & KX673894-96 \\
\hline & & Knipowitschia milleri & KX673916-18 \\
\hline 17 & Acheron River & Knipowitschia milleri & KX673923-25 \\
\hline \multirow[t]{2}{*}{18} & Kalamas River & Economidichthys pygmaeus & KX673905-07 \\
\hline & & Knipowitschia milleri & KX673919-22 \\
\hline \multicolumn{4}{|c|}{ Adriatic } \\
\hline \multirow[t]{9}{*}{19} & Venetian Lagoon & Knipowitschia panizzae & KX673964-67 \\
\hline & & Ninnigobius canestrinii & KX673968-71 \\
\hline & & Pomatoschistus marmoratus & KX673973-75 \\
\hline & Towuti Lake (Indonesia) & Mugilogobius adeia & KM887159 \\
\hline & Towuti Lake (Indonesia) & Mugilogobius latifrons & KM887161 \\
\hline & Towuti Lake (Indonesia) & Mugilogobius hitam & KM887169 \\
\hline & Tyligul Estuary (Ukraine) & Zosterisessor ophiocephalus & EU444698 \\
\hline & Israel & Gobius niger & KM538356 \\
\hline & Baltic Sea & Gobius niger & KM077839 \\
\hline
\end{tabular}

Site number refers to the location of each sampling site as shown in Figure 1. 


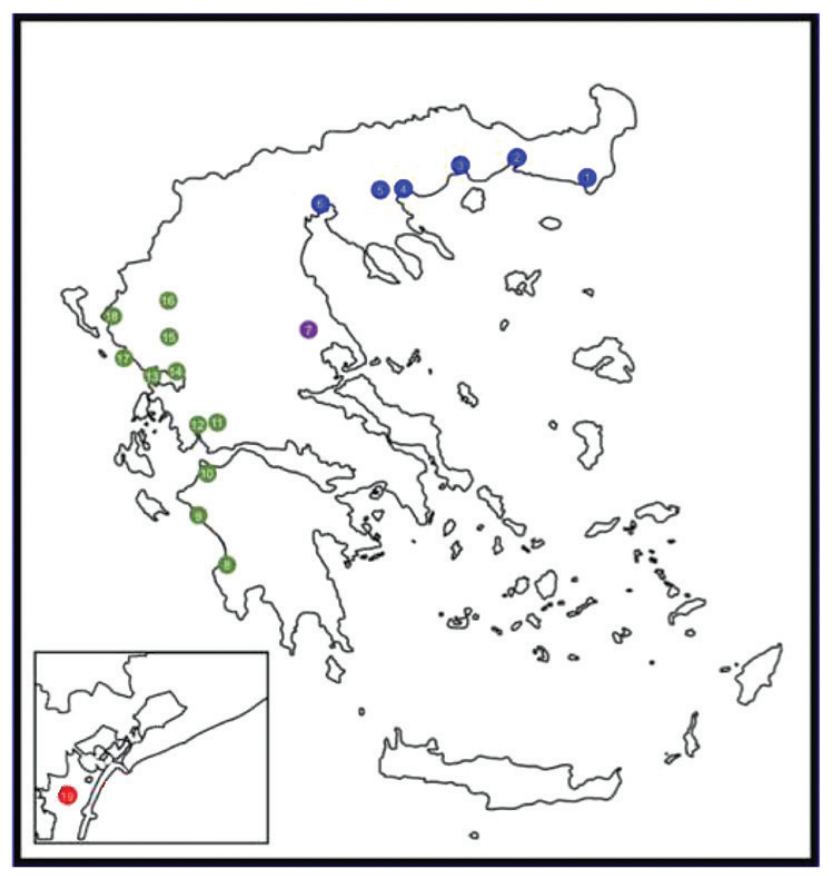

Figure 1. Map of sampling localities in Greece and the Venetian Lagoon (inset). Sites indicated in blue are on the Aegean coast; purple indicates Thessaly; green localities are on the Ionian coast; and the Adriatic (Venetian Lagoon) is indicated in red. Locality numbers correspond to those given in Table 1.

primers and unincorporated nucleotides removed from successful reactions with spin column purification kits (Nucleospin Extract II; Macherey-Nagel). The amplified fragments were then sent out for bidirectional sequencing at the VBC Biotech Service GmbH (Wien, Austria).

We generated $C O I$ sequence data from 83 representatives of the species $N$. canestrinii, Pomatoschistus marmoratus (Risso, 1810) and Knipowitschia panizzae (Verga, 1841) from Venice; Economidichthys trichonis Economidis \& Miller, 1990, Economidichthys pygmaeus (Holly, 1929) and Knipowitschia milleri (Ahnelt \& Bianco, 1990) from western Greece (Ionian sea); and Knipowitschia thessala (Vinciguerra, 1921), Knipowitschia caucasica (Berg, 1916) and P. marmoratus (Risso, 1810) from northern Greece (Thessaly on the northern Aegean coast). Sequences were $625 \mathrm{bp}$ in length and are deposited in GenBank under the accession numbers KX673893-KX673975. We also sequenced five outgroup taxa, including single exemplars of Mugilogobius latifrons (Boulenger, 1897), Mugilogobius adeia Larson \& Kottelat, 1992, Mugilogobius hitam Larson, Geiger, Hadiaty \& Herder, 2014 (Gobionellidae, Mugilogobius lineage) and one individual of Zosterisessor ophiocephalus (Pallas, 1814) and two of Gobius niger Linnaeus, 1785 (Gobiidae, Gobius lineage).

In addition to the newly determined sequences from Greece and the Venetian Lagoon, we used archived
DNA barcode sequences for sand goby species obtained from GenBank and largely derived from the works of Costa et al. (2012), Geiger et al. (2014), Knebelsberger \& Thiel (2014) and Landi et al. (2014). GenBank numbers of archived DNA barcode sequences used in the analysis are given in Table 2 . We assembled a total of 271 individual sequences from 24 nominal sand goby species, with sampling that girds the European continent, from the Baltic Sea in the north, throughout the North Sea, Northeastern Atlantic and the Mediterranean, Aegean and Ionian seas and many coastal freshwater drainages. Following the taxonomy given by Froese \& Pauly (2017), we lack the two species of Knipowitschia [Knipowitschia longecaudata (Kessler, 1877) and Knipowitschia iljini Berg, 1931] known from the Black, Azov and Caspian seas, Knipowitschia bergi (Iljin, 1928) from the Caspian sea, one of the two sympatric species known from a brackish coastal lake near the southern coast of Turkey (Knipowitschia caunosi Ahnelt, 2011); and five Pomatoschistus: Pomatoschistus bathi Miller, 1982 from the Adriatic and Eastern Mediterranean, Pomatoschistus knerii (Steindachner, 1861) from the coast of Croatia, Pomatoschistus nanus Engin \& Seyhan, 2017 and Pomatoschistus anatoliae Engin \& Innal, 2017 from the coast of Turkey, and Pomatoschistus quagga (Heckel, 1839) from the Western Mediterranean. In particular, P. quagga is of interest because earlier phylogenetic studies 
Table 2. Archived COI sequences from GenBank used in this study

\begin{tabular}{|c|c|}
\hline KJ553311 & E. pygmaeus \\
\hline KJ553316 & E. pygmaeus \\
\hline KJ553364 & E. pygmaeus \\
\hline KJ553482 & E. pygmaeus \\
\hline KJ553547 & E. pygmaeus \\
\hline KJ553595 & E. pygmaeus \\
\hline KJ553631 & E. pygmaeus \\
\hline KJ553325 & E. trichonis \\
\hline KJ553425 & E. trichonis \\
\hline KJ553450 & E. trichonis \\
\hline KJ553457 & E. trichonis \\
\hline KJ553322 & K. byblisia \\
\hline KJ553368 & K. byblisia \\
\hline KJ553411 & K. byblisia \\
\hline KJ553412 & K. byblisia \\
\hline KJ553454 & K. byblisia \\
\hline KJ553539 & K. byblisia \\
\hline KJ553570 & K. byblisia \\
\hline KJ553602 & K. byblisia \\
\hline KJ553641 & K. byblisia \\
\hline HQ600736 & K. caucasica \\
\hline KJ553350 & K. caucasica \\
\hline KJ553351 & K. caucasica \\
\hline KJ553376 & K. caucasica \\
\hline KJ553407 & K. caucasica \\
\hline KJ553419 & K. caucasica \\
\hline KJ553420 & K. caucasica \\
\hline KJ553455 & K. caucasica \\
\hline KJ553557 & K. caucasica \\
\hline KJ553566 & K. caucasica \\
\hline KJ553584 & K. caucasica \\
\hline KJ553633 & K. caucasica \\
\hline KJ553390 & K. ephesi \\
\hline KJ553459 & K. ephesi \\
\hline KJ553609 & K. ephesi \\
\hline KJ553345 & $K$. mermere \\
\hline KJ553363 & $K$. mermere \\
\hline KJ553410 & $K$. mermere \\
\hline KJ553448 & $K$. mermere \\
\hline KJ553452 & $K$. mermere \\
\hline KJ553480 & $K$. mermere \\
\hline KJ553611 & $K$. mermere \\
\hline KJ553365 & K. milleri \\
\hline KJ553395 & K. milleri \\
\hline KJ553398 & K. milleri \\
\hline KJ553444 & K. milleri \\
\hline KJ553465 & K. milleri \\
\hline KJ553512 & K. milleri \\
\hline KJ553527 & K. milleri \\
\hline KJ553530 & K. milleri \\
\hline KJ553558 & K. milleri \\
\hline KJ553576 & K. milleri \\
\hline KJ553591 & K. milleri \\
\hline KJ553658 & K. milleri \\
\hline
\end{tabular}

Table 2. Continued

\begin{tabular}{|c|c|}
\hline KJ553378 & K. montenegrina \\
\hline KJ553384 & K. montenegrina \\
\hline KJ553417 & K. montenegrina \\
\hline KJ553451 & K. montenegrina \\
\hline KJ553543 & K. montenegrina \\
\hline KJ553352 & K. mrakovcici \\
\hline KJ553370 & K. mrakovcici \\
\hline KJ553375 & K. mrakovcici \\
\hline KJ553514 & K. mrakovcici \\
\hline KJ553521 & K. mrakovcici \\
\hline KJ553537 & K. mrakovcici \\
\hline KJ553555 & K. mrakovcici \\
\hline KJ553594 & K. mrakovcici \\
\hline KJ552355 & K. panizzae \\
\hline KJ553310 & $K$. panizzae \\
\hline KJ553342 & K. panizzae \\
\hline KJ553355 & K. panizzae \\
\hline KJ553377 & K. panizzae \\
\hline KJ553400 & $K$. panizzae \\
\hline KJ553423 & K. panizzae \\
\hline KJ553424 & K. panizzae \\
\hline KJ553437 & K. panizzae \\
\hline KJ553468 & K. panizzae \\
\hline KJ553469 & K. panizzae \\
\hline KJ553491 & K. panizzae \\
\hline KJ553511 & K. panizzae \\
\hline KJ553579 & $K$. panizzae \\
\hline KJ553613 & K. panizzae \\
\hline KJ553643 & K. panizzae \\
\hline KJ553652 & K. panizzae \\
\hline KJ553466 & $K$. radovici \\
\hline KJ553481 & K. radovici \\
\hline KJ553552 & K. radovici \\
\hline KJ553599 & K. radovici \\
\hline KJ553636 & K. radovici \\
\hline KJ553656 & K. radovici \\
\hline KJ553439 & K. thessala \\
\hline KJ553464 & K. thessala \\
\hline KJ553503 & K. thessala \\
\hline KJ553809 & N. canestrinii \\
\hline KJ554046 & N. canestrinii \\
\hline KJ554069 & N. canestrinii \\
\hline KJ553666 & N. montenegrensis \\
\hline KJ553703 & N. montenegrensis \\
\hline KJ553759 & N. montenegrensis \\
\hline KJ554044 & N. montenegrensis \\
\hline KJ554070 & N. montenegrensis \\
\hline KJ553751 & O. croaticus \\
\hline KJ553780 & O. croaticus \\
\hline KJ553811 & O. croaticus \\
\hline KJ553834 & O. croaticus \\
\hline KJ553854 & O. croaticus \\
\hline KJ554032 & O. croaticus \\
\hline KJ554053 & O. croaticus \\
\hline KJ553912 & O. punctatissimus \\
\hline
\end{tabular}


Table 2. Continued

\begin{tabular}{|c|c|}
\hline KJ553993 & O. punctatissimus \\
\hline KJ128503 & P. flavescens \\
\hline KJ128504 & P. flavescens \\
\hline KM077830 & P. flavescens \\
\hline KM077831 & P. flavescens \\
\hline KM077832 & P. flavescens \\
\hline KM077833 & P. flavescens \\
\hline KM077834 & P. flavescens \\
\hline KM077835 & P. flavescens \\
\hline JQ775029 & P. lozanoi \\
\hline JQ775030 & P. lozanoi \\
\hline JQ775031 & P. lozanoi \\
\hline JQ775032 & P. lozanoi \\
\hline JQ775033 & P. lozanoi \\
\hline KM077847 & P. lozanoi \\
\hline KM077848 & P. lozanoi \\
\hline KM077849 & P. lozanoi \\
\hline KJ554258 & P. marmoratus \\
\hline KJ554272 & P. marmoratus \\
\hline KJ554281 & P. marmoratus \\
\hline KJ554294 & P. marmoratus \\
\hline KJ554300 & P. marmoratus \\
\hline KJ554461 & P. marmoratus \\
\hline KJ709583 & P. marmoratus \\
\hline KJ709584 & P. marmoratus \\
\hline KJ128585 & P. microps \\
\hline KJ128586 & P. microps \\
\hline KJ554119 & P. microps \\
\hline KJ554147 & P. microps \\
\hline KJ554336 & P. microps \\
\hline KJ554517 & P. microps \\
\hline KJ768285 & P. microps \\
\hline KJ768286 & P. microps \\
\hline KJ768287 & P. microps \\
\hline KM077850 & P. microps \\
\hline KM077851 & P. microps \\
\hline KM077852 & P. microps \\
\hline KM077853 & P. microps \\
\hline KM077854 & P. microps \\
\hline KM077855 & P. microps \\
\hline KM077856 & P. microps \\
\hline KJ128587 & P. minutus \\
\hline KJ128588 & P. minutus \\
\hline KM077857 & P. minutus \\
\hline KM077858 & P. minutus \\
\hline KM077859 & P. minutus \\
\hline KM077860 & P. minutus \\
\hline KM077861 & P. minutus \\
\hline KM077862 & P. minutus \\
\hline KM077863 & P. minutus \\
\hline KM077864 & P. minutus \\
\hline KM077865 & P. minutus \\
\hline KM077866 & P. minutus \\
\hline KJ128589 & P. norvegicus \\
\hline KJ128590 & P. norvegicus \\
\hline
\end{tabular}

Table 2. Continued

\begin{tabular}{ll}
\hline $\mathrm{KM} 077867$ & P. norvegicus \\
$\mathrm{KM} 077868$ & P. norvegicus \\
$\mathrm{KM} 077869$ & P. norvegicus \\
$\mathrm{KM} 077870$ & P. norvegicus \\
$\mathrm{KM} 077871$ & P. norvegicus \\
$\mathrm{KM} 077872$ & P. norvegicus \\
$\mathrm{KM} 077873$ & P. norvegicus \\
$\mathrm{KM} 077874$ & P. norvegicus \\
$\mathrm{KJ} 128591$ & P. pictus \\
$\mathrm{KM} 077875$ & P. pictus \\
$\mathrm{KM} 077876$ & $P$. pictus \\
$\mathrm{KM} 077877$ & $P$. pictus \\
$\mathrm{KM} 077878$ & P. pictus \\
FJ751920 & P. tortonesi \\
FJ751921 & P. tortonesi \\
FJ751922 & P. tortonesi \\
KJ709585 & P. tortonesi \\
KJ709586 & P. tortonesi
\end{tabular}

have placed it outside Pomatoschistus and suggested a closer relationship to Knipowitschia, specifically K. panizzae (Penzo et al., 1988; Huyse et al., 2004; Vanhove et al., 2012).

\section{PHYLOGENETIC ANALYSIS AND CALIBRATION}

We assembled the data matrix using Geneious (Biomatters, Ltd) version 10.1.3, aligned the sequences based on the amino acid translation, and adjusted and trimmed the alignment by eye. We used MrBayes version 2.0.9 (Geneious plugin) to infer phylogeny, specifying a general time reversible, with gamma-distributed rate variation and invariant sites $(\mathrm{GTR}+\mathrm{G}+\mathrm{I})$ substitution model, as chosen by the $\mathrm{R}$ module phangorn (Schliep, 2011 ). We ran the analysis for $10.0 \times 10^{7}$ generations, with four simultaneous chains, sampling every 1000 replications, discarding the first 10\% of trees as burn-in and then constructing a 50\% majority-rule consensus phylogeny of the remaining trees. In order to calibrate the phylogeny, we reduced the data set to two exemplars of each sand goby species (three for P. marmoratus, in order to represent the geographical range) to avoid loss of computational efficiency as a result of the intraspecific polytomies. We inferred a Bayesian tree as outlined above and performed the calibration analysis on a matrix of 49 individuals (including the six outgroup exemplars) with Beast 1.7.5 (Drummond et al., 2012), run with an uncorrelated lognormal relaxed clock model and a birth/death speciation prior. We assigned a calibration of $48.7 \mathrm{Mya}$, applied as a normal prior, to the node subtending the family Gobionellidae, including Mugilogobius in addition to the sand gobies. This calibration was derived from the analysis of Thacker (2015). We also applied calibrations to each of the genera Economidichthys, Pomatoschistus and 
Knipowitschia. Dates for the origins of these sand goby genera were derived from Schwarzhans et al. (2017). We applied the ages of the earliest known Economidichthys (15.0 Mya),Pomatoschistus (16.0 Mya) and Knipowitschia (13.0 Mya) as exponential priors. We ran the Beast analysis for $10.0 \times 10^{7}$ generations, with trees sampled every 1000 generations, and discarded the first $10 \%$ as burnin. At the end of the analyses, estimated effective sample sizes (ESS) for all parameters well exceeded 200, and we constructed maximum clade credibility consensus tree using TreeAnnotator 1.7.5 (Drummond et al., 2012) and visualized this tree using FigTree 1.3.1 (Rambaut, 1999).

\section{RESULTS}

The Bayesian hypothesis of relationships is shown in Figure 2. The tree is rooted with Gobius and Zosterisessor (Gobius lineage, family Gobiidae) as distal outgroups, with representatives of Mugilogobius (Mugilogobius lineage, family Gobionellidae) serving as the more proximal outgroup. In total, the hypothesis includes a novel sequence for 83 sand goby individuals and six outgroup individuals (five species), combined with 182 COI barcode sequences from GenBank. In addition to the five outgroup species, the hypothesis includes all species of Ninnigobius, Orsinigobius and Economidichthys (two each) plus eight Pomatoschistus (including Pomatoschistus flavescens). Within Knipowitschia, eight species-level clades are resolved, but they contain 12 species names. This is the most comprehensive sand goby analysis to date, and the first to include a gobionellid outgroup, in keeping with the placement of sand gobies in Gobionellidae rather than Gobiidae (Thacker \& Roje, 2011; Thacker, 2013).

Across the topology, posterior support values are weakest at the intergeneric nodes, but much stronger for individual species and smaller species groups. Support for the monophyly of sand gobies is strong, at 99\%. Within sand gobies, the deepest split is between Ninnigobius and the remainder of the genera. Miller \& Šanda (2008), in their description of $N$. montenegrensis, discuss the differences between that species and N. canestrinii, relative to Pomatoschistus; Ninnigobius species have reductions in head pores and scalation, a unique spotted pigment pattern and a freshwater habitat, rather than marine. They concluded that the only unique character among those was the colour pattern, which did not in itself justify a separation of those two species into a separate genus. Our analysis concurs with Geiger et al. (2014) in supporting the recognition of Ninnigobius based on molecular data. Our hypothesis differs in recovering $N$. canestrinii as paraphyletic with respect to $N$. montenegrensis. Although the $N$. montenegrensis individuals are distinct, the internodes among $N$. canestrinii are short and may simply be poorly resolved.

Outside Ninnigobius, the genus Pomatoschistus is resolved as three lineages that are sequential sister taxa to a clade including Knipowitschia, Economidichthys and Orsinigobius. The lineages include Pomatoschistus pictus (Malm, 1865) and P. flavescens; the 'Pomatoschistus minutus complex' consisting of $P$. minutus (Pallas, 1770), Pomatoschistus norvegicus (Collett, 1902) and Pomatoschistus lozanoi (deBuen, 1923); and a clade including Pomatoschistus tortonesi Miller, 1969, P. marmoratus (Risso, 1810) and Pomatoschistus microps (Kroyer, 1838). Support for each of these three clades is high, at $99 \%$, but their placement relative to each other, and to the other sand goby taxa, is poorly resolved. These same three clades (less P. tortonesi and P. marmoratus) were also recovered by Knebelsberger \& Thiel (2014), with similar weak support for their interrelationships. The clades reflect biogeographical and ecological patterns; most Pomatoschistus are distributed in the Northeastern Atlantic and are nearshore but exclusively marine (P. minutus in the Adriatic, which we did not sample, is genetically distinct and might represent a new species; Stefanni \& Thorley, 2003; Gysels et al., 2004). Pomatoschistus microps, P. marmoratus and $P$. tortonesi are tolerant of lower salinities, inhabiting estuaries and marshes, and range into both the Mediterranean and the Black Sea.

In a separate clade from the Pomatoschistus lineages, the genera Knipowitschia, Orsinigobius and Economidichthys are resolved as a polytomy, but support for the monophyly of each genus is strong (99\%). Orsinigobius includes two species (O. punctatissimus and $O$. croaticus) known from Adriatic freshwater drainages of Italy and Croatia that have been separated from Knipowitschia owing to their reductions in head pores. Another species, $K$. milleri, known from the Acheron river in western Greece, was originally described in Orsinigobius (Ahnelt \& Bianco, 1990), but later studies (Miller, 2004; Kottelat \& Freyhof, 2007; Freyhof, 2011) included it in Knipowitschia, a placement that we confirm. The two Economidichthys species (E. pygmaeus and $E$.trichonis) from freshwaters in western Greece are grouped together, as are all of the Knipowitschia.

Within Knipowitschia, we recover three lineages. The first contains $K$. caucasica, sampled from eastern Greece and Turkey and including four individuals classified as Knipowitschia ephesi Ahnelt, 1995, a species endemic to a brackish coastal lake near Marmara, on the Aegean coast of Turkey. There is quite a bit of structure within $K$. caucasica, and it is possible that there are cryptic or unidentified species within its wide range and that further sampling of $K$. ephesi will resolve that taxon as distinct. Our sampling did not include $K$. caucasica from the Adriatic, so we were 


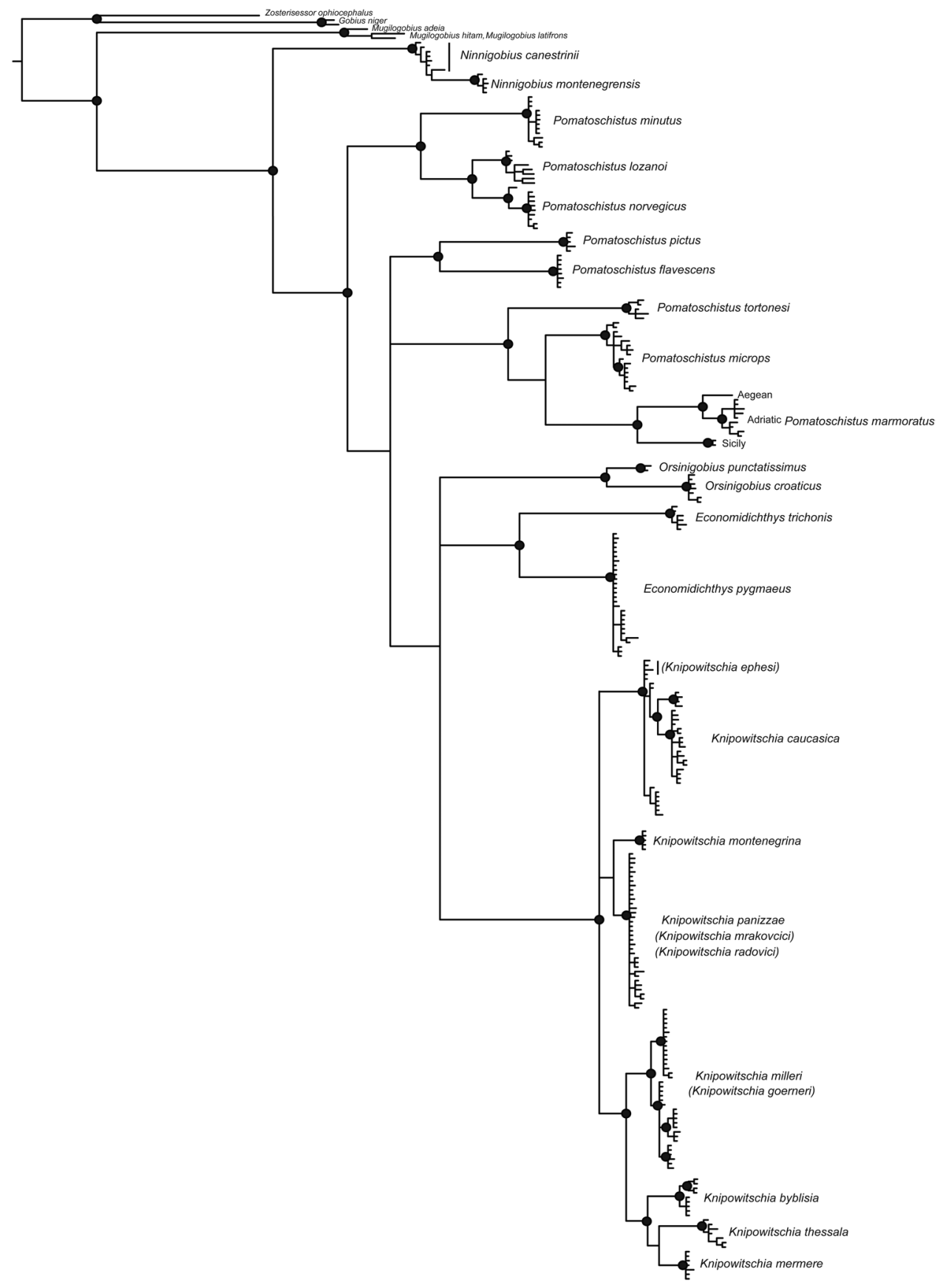

Figure 2. Bayesian phylogenetic hypothesis of sand gobies, including 265 individuals plus six outgroups. Black circles at nodes indicate 95-100\% posterior probability, and localities of Pomatoschistus marmoratus individuals are indicated. Ninnigobius canestrinii is paraphyletic with respect to Ninnigobius montenegrensis, and Pomatoschistus is paraphyletic in this hypothesis, although support values along the phylogenetic backbone are not strong. Individuals identified as Knipowitschia ephesi are indicated; they are recovered among Knipowitschia caucasica, although there is structure within K. caucasica that might warrant recognition as distinct species. Within Knipowitschia panizzae are individuals identified as Knipowitschia mrakovcici and Knipowitschia radovici, and here there is little intraspecific structure. Individuals identified as Knipowitschia goerneri are included within Knipowitschia milleri. Two clades are evident within Knipowitschia byblisia, one of which might correspond to the sympatric Knipowitschia caunosi. 
unable to determine whether or not that population is a distinct species, as suggested by Economidis \& Miller (1990) and Kovačić \& Pallaoro (2003). A second clade resolves Knipowitschia montenegrina Kovačić \& Sanda, 2008 as sister to a large assemblage with little phylogenetic structure, consisting of individuals assigned to Knipowitschia mrakovcici Miller, 2009, Knipowitschia radovici Kovačić, 2005 and K. paniz$z a e$; all those are known from the Adriatic drainages of Croatia and Montenegro. Finally, a third clade includes three clades, one of which contains individuals from that same lake, classified as Knipowitschia byblisia Ahnelt, 2011, but including two subgroups that may coincide with $K$. byblisia and similar endemic species, $K$. caunosi [those sequences derived from the study of Geiger et al. (2014) and are vouchered in the collection of Jörg Freyhof; we did not examine them]. That clade is sister to two other species, $K$. thessala from Greece and Knipowitschia mermere Ahnelt, 1995 from the same Turkish lake, and that clade is sister to K. milleri, also from Greece. Within the K. milleri clade were included several individuals provisionally classified as Knipowitschia goerneri (Ahnelt, 1991), a species from the Ionian coast of Greece, including Corfu Island. These individuals were mixed among specimens of $K$. milleri; therefore, we consider $K$. goerneri a synonym.

The calibrated Bayesian phylogeny is shown in Figure 3. Although the sampling is much reduced, the species-level topology is equivalent to the complete analysis, except that Pomatoschistus is recovered as monophyletic (although poorly supported). In the calibrated analysis, Beast has also resolved the polytomy among Knipowitschia, Orsinigobius and Economidichthys. We infer a crown age of 32.6 Mya (95\% highest posterior density range 24.9-41.5 Mya) for the sand gobies, slightly after the Eocene/Oligocene boundary. The stem ages of genera (except Ninnigobius at 32.6 Mya) range from 22.3 to $26.3 \mathrm{Mya}$ in the late Oligocene/early Miocene, a narrow span that is consistent with the weak resolution along that phylogenetic backbone and, possibly, with a rapid radiation of genera. Given the uncertainty among those nodes, the dates (particularly the sequence of divergences) should be interpreted cautiously.

The genera and subgeneric lineages are all well supported, at $100 \%$ (except Pomatoschistus). Inferred crown ages and confidence intervals for sand goby genera and subgroups are given in Table 3, and Kimura two parameter $(\mathrm{K} 2 \mathrm{P})$ distances among taxa are provided in the Supporting Information (Table S1). The youngest ages (2.7-5.8 Mya) are in the clades distributed in the Adriatic, including Ninnigobius, Orsinigobius and the $K$. panizzae/K. montenegrina lineage. Although the stem lineages of those clades are much older, the crown age indicates the period of most recent diversification.

\section{DISCUSSION}

Our phylogeny incorporates and unites data for sand gobies from across their geographical range in the northeastern Atlantic, Mediterranean, Balkanian and Ponto-Caspian regions. This is the most comprehensive phylogenetic hypothesis yet proposed for sand gobies, and it provides clarification of species and genus boundaries that, in turn, informs the taxonomy. We confirm that the smaller genera Ninnigobius and Orsinigobius are distinct, that the Atlantic species formerly distinguished as G. flavescens is part of Pomatoschistus, and that Orsinigobius, Economidichthys and Knipowitschia form a clade. Within Knipowitschia, we show that one of the species from the lake near Marmara (K. ephesi) is nested within $K$. caucasica, but recover the other lake species as distinct, including two clades that correspond to $K$. byblisia and, possibly, also $K$. caunosi, sympatric endemics. In contrast, and as first determined by Geiger et al. (2014), we show that K. $m r a-$ kovcici, $K$. radovici and K. panizzae are not distinct; therefore, the older name, K. panizzae, should be used for this entire group. We also confirm that $K$. goerneri from western Greece is included within $K$. milleri. This comprehensive analysis clarifies sand goby relationships and allows assessment of the current taxonomy. Relationships of species within both Pomatoschistus and Knipowitschia also agree well (where they overlap) with the earlier studies of Huyse et al. (2004), Knebelsberger \& Thiel (2014) and Vukić et al. (2016).

In the context of our phylogeny, we can interpret the geographical distribution of sand goby lineages. The most obvious distinction is between the generally Atlantic/Western Mediterranean marine species of Pomatoschistus and the euryhaline- to freshwaterdwelling Knipowitschia in the Eastern Mediterranean, Black and Caspian seas. These genera both include a few wide-ranging generalists in addition to a suite of species with more restricted distributions. The smaller genera Ninnigobius, Orsinigobius and Economidichthys are all restricted to drainages of the Adriatic and Ionian seas, and some lineages of Knipowitschia and populations of Pomatoschistus also inhabit that area, making it the centre of diversity for sand gobies, with a total of 17 species.

The Mediterranean basin has undergone a series of complex hydrographic and geological changes over the past 20 Myr. The terminal Tethyan Event, the collision of Africa with Asia that separated the contiguous Tethys seaway, took place gradually in the Miocene, 12-18 Mya. This event isolated the goby lineages in the Mediterranean and Atlantic from those in the tropical Indian Ocean (Thacker, 2015); what is now the Mediterranean is a remnant of the western Tethys sea. To the north and east of the Alps, encompassing the Black and Caspian Sea basins, was an 


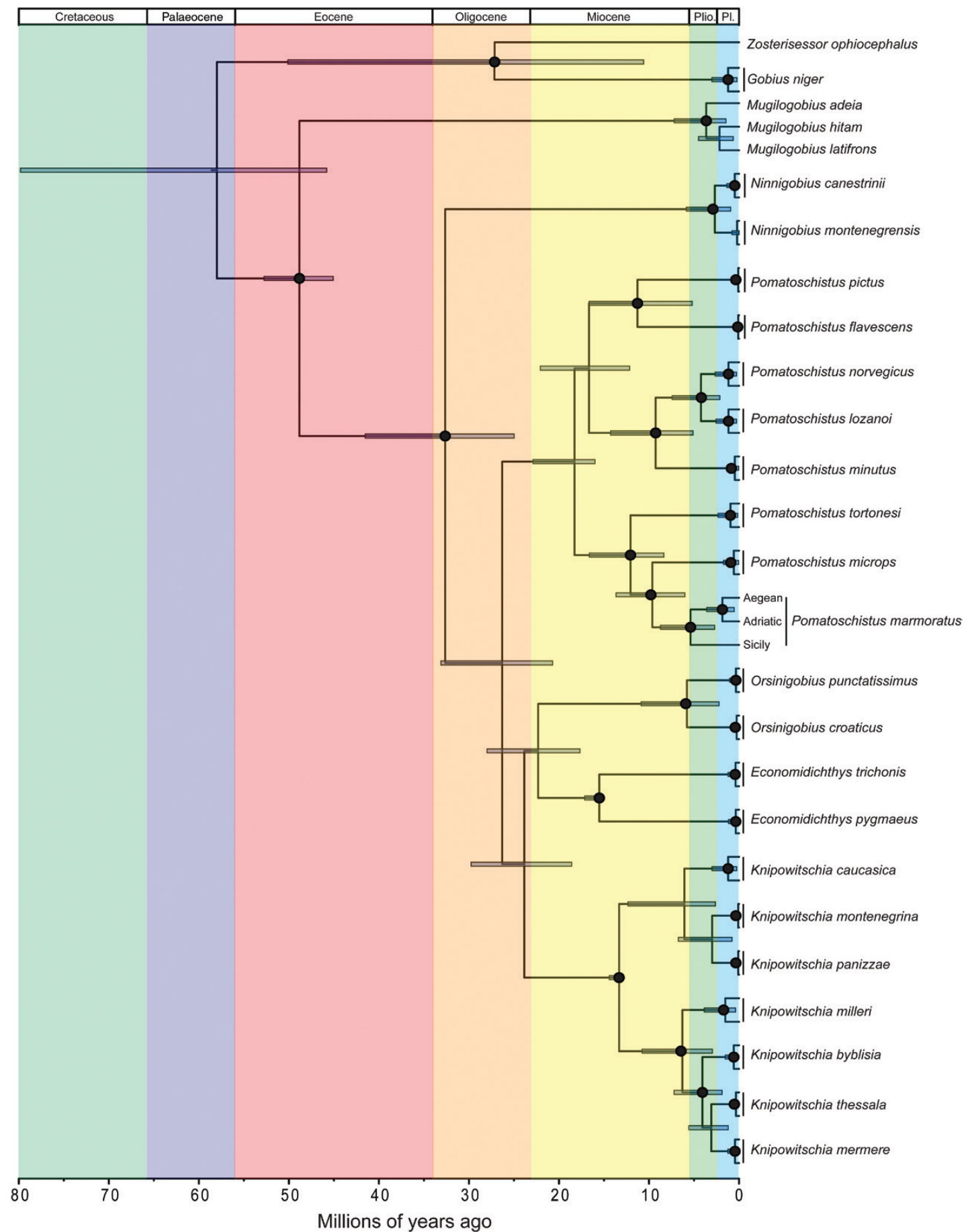

Figure 3. Phylogenyof sand gobies, based on a reduced data set of 43 individuals plus outgroups. The hypothesis is calibrated with a legacy date of $48.7 \mathrm{Mya}$ at the base of Gobionellidae (from Thacker, 2015), and fossil calibrations for the origins of Economidichthys (15.0 Mya), Pomatoschistus (16.0 Mya) and Knipowitschia (13.0 Mya) derived from Schwarzhans et al. (2017). Error bars indicate $95 \%$ highest posterior density, and black circles at nodes indicate 95-100\% posterior probability. Localities of different Pomatoschistus marmoratus individuals are indicated.

inland sea known as the Paratethys throughout the Miocene. The Paratethys was isolated over most of the period of Tethys closure, except for occasional marine transgressions (Orszag-Sperber, 2006; Schwarzhans et al., 2017). It was brackish to freshwater habitat, owing to the inflow of several large rivers, with 
Table 3. Inferred crown ages (in millions of years ago) with $95 \%$ confidence intervals (in parentheses), and geographical ranges and habitat for sand goby clades

\begin{tabular}{|c|c|c|}
\hline Clade & Age (Mya) & Range \\
\hline Sand goby clade & $32.6(24.9-41.5)$ & Europe seas and rivers \\
\hline Ninnigobius & $2.7(0.9-5.8)$ & Adriatic drainages, $\mathrm{FW}$ \\
\hline Pomatoschistus & $18.3(16.0-22.9)$ & NE Atlantic, Western Mediterranean, Adriatic marine \\
\hline P. minutus /P. lozanoi/P. norvegicus clade & $9.3(5.1-14.3)$ & NE Atlantic, North Sea, Baltic Sea, marine \\
\hline P. pictus/P. flavescens clade & $11.3(5.2-16.7)$ & NE Atlantic, North Sea, Baltic Sea, marine \\
\hline P. tortonesi/P. marmoratus/P. microps clade & $12.1(8.3-16.6)$ & NE Atlantic, Western Mediterranean, Adriatic, marine \\
\hline Knipowitschia & $13.3(13.0-14.4)$ & $\begin{array}{l}\text { Eastern Mediterranean, Adriatic, Black, Caspian, FW, } \\
\text { brackish }\end{array}$ \\
\hline$K$. panizzae/K. montenegrina clade & $3.0(0.8-6.7)$ & Adriatic drainages, FW \\
\hline $\begin{array}{l}\text { K. milleri/K. thessala/K. mermere/K. byblisia } \\
\text { clade }\end{array}$ & $6.3(3.0-10.8)$ & $\begin{array}{l}\text { Eastern Mediterranean, Adriatic, Black, Caspian, FW, } \\
\text { brackish }\end{array}$ \\
\hline Orsinigobius & $5.8(0.9-5.8)$ & Adriatic drainages, $\mathrm{FW}$ \\
\hline Economidichthys & $15.5(15.0-17.1)$ & Greece (Ionian Sea drainages), FW \\
\hline
\end{tabular}

Abbreviations: FW, freshwater; NE, northeastern.

particularly acute reductions in salinity after its final separation from the Tethys at 12 Mya (Rögl, 1998, 1999b).

During the Pliocene and Pleistocene, the Paratethys gradually shrank to its current remnants: the Black, Caspian and Aral seas. In the same period, between 5 and 6 Mya, the strait of Gibraltar closed, resulting in the gradual drying of the Mediterranean known as the Messinian Salinity Crisis (MSC; Hallam, 1994; Krijgsman et al., 1999; Duggen et al., 2003; OrszagSperber, 2006). Various hypotheses on goby speciation in the Mediterranean region (Penzo et al., 1998; Stefanni \& Thorley, 2003; Huyse et al., 2004; Vanhove et al., 2012) have been put forward, including different interpretations of the role of tectonic and sea-level changes during the MSC vs. those caused by Pleistocene glaciation cycles. The MSC is characterized by a drastic drop in sea level and the establishment of brackish lakes throughout the Mediterranean region, a period known as the Lago Mare phase (Penzo et al., 1998; Huyse et al., 2004). One possibility is that sand gobies evolved in these fresh and brackish environments and then radiated during subsequent phases characterized by higher sea levels, reflooding and salinity increases (Huyse et al., 2004; Malavasi et al., 2012). It is also possible that much later, during the Pleistocene, a series of glaciations and consequent additional fluctuations in sea levels triggered population subdivision and bursts of speciation (Stefanni \& Thorley, 2003). Either or both (or neither) of these periods of tectonic change may have facilitated diversification among sand gobies, but distinguishing among those theories requires a time scale for sand goby diversification. A calibrated phylogenetic study of European Cyprinidae, a group also thought to have diversified in concert with the
Lago Mare phase, showed instead that their diversification occurred as early as the Oligocene, well predating the Miocene and Pliocene events of the MSC (Levy, Doadrio \& Almada, 2009).

Previous phylogenetic works on sand gobies have used molecular clocks, with or without a biogeographical calibration, as a source of evolutionary timing estimates for sand gobies. Huyse et al. (2004) used mitochondrial ribosomal genes to infer sand goby phylogeny, which showed a rapid divergence (short internodes) among genera along the backbone of the tree. They calibrated this divergence with a biogeographical date of 5.6 Mya, on the assumption that the diversification of genera, and the adoption of freshwater lifestyle in Economidichthys, Ninnigobius and Orsinigobius, corresponded to the Lago Mare phase of the MSC. Their resultant clock estimate of $1.4 \%$ pairwise divergence $(0.7 \%$ lineagewise divergence) per million years is comparable to mitochondrial divergence rates in other vertebrates. They then further postulated that more recent species diversification within Pomatoschistus (in particular, the P. minutus complex) was related to Pleistocene glaciation between 1.94 and 1.18 Mya that constrained and fragmented the ranges available to species in the northeastern Atlantic. Populations of Pomatoschistus in the Adriatic would also have been isolated by sea-level regression in the Mediterranean at this time. In contrast, Penzo et al. (1998), also based on mitochondrial ribosomal genes, included four sand goby taxa in a larger phylogeny of Mediterranean gobies and placed the diversification of sand gobies at either 2.6 or $12.4 \mathrm{Mya}$, as calibrated by alternate transversion-only clocks. The older date is derived from a $0.14 \%$ lineagewise transversion change per million year vertebrate clock estimate, and 
the younger from assuming that the split between sand gobies and the more distantly related genera Gobius, Zosterisessor and Padogobius was related to the Lago Mare phase. Vanhove et al. (2012), also using mitochondrial ribosomal genes, examined the eastern Mediterranean lineages and applied two clock calibrations, 0.5 and $1.5 \%$ lineagewise divergence per million years. These calibrations yield upper and lower bounds on the origin of sand gobies at 2.9 and 9.0 Mya, and diversification within the genera at 2.0-6.0 Mya. These estimates correlate well with the Lago Mare phase at 5.9 Mya, followed by a diversification within genera somewhat later, concordant with Pleistocene glaciation.

Our calibrated phylogeny (Fig. 3; ages of major clades given in Table 3) uses fossil calibrations (rather than a molecular clock or biogeographical calibration) and indicates that crown ages for sand goby genera are much older than previous estimates, ranging from the mid-Miocene (Pomatoschistus at 18.3 Mya; Economidichthys at 15.5 Mya; Knipowitschia at $13.3 \mathrm{Mya}$ ) to the late Miocene/early Pliocene (Orsinogobius at 5.8 Mya; Ninnigobius at 2.7 Mya). These crown radiations in freshwater clades (Ninnigobius, Orsinigobius and the two clades within Knipowitschia) are generally younger than the marine radiations (Pomatoschistus clades), although the comparatively old Economidichthys is an exception (Table 3). The older, mid-Miocene radiations are correlated with the closure of the Tethys seaway, the isolation and decreasing salinity in the Paratethys, and the establishment of cooler environments in the Mediterranean after its separation from the Indian Ocean (Rögl, 1998, 1999b); the origin of Economidichthys occurred at roughly the same time as the emergence of Greece owing to sea-level regression (Rögl, 1999a). Pomatoschistus, Economidichthys and Knipowitschia had become established long before the MSC, and their diversification is more likely to be related to the isolation and fluctuations in the Tethys and Paratethys.

In contrast, the younger (late Miocene/early Pliocene) diversification events in the freshwater sand goby lineages Ninnigobius, Orsinigobius and the two Knipowitschia clades all occurred exclusively or partly in the Adriatic region, and all occurred during the MSC, a period of dramatically reduced aquatic habitats and overall cooler temperatures in the Mediterranean region (Rögl, 1998, 1999b). The eastern Mediterranean would have been reduced to brackish lakes (Lago Mare), with the Adriatic exposed except for rivers draining from the Balkans and the Alps. Marine species that could persist in the Atlantic would potentially reoccupy the Mediterranean after the MSC, but freshwater species would be isolated and fragmented, probably promoting speciation. Orsinigobius, Ninnigobius and Knipowitschia clades have widely varying stem ages (Ninnigobius is the oldest among sand gobies, dating back to the early Oligocene), but all experienced their crown diversification around the time of the MSC.

By the Pleistocene, all the sand goby species were established, and only diversification within species was occurring. Structure within species is generally shallow, with the exception of some unusually deep structure within $P$. marmoratus. In that species, the individuals sampled from Sicily are distinct from another clade including one individual from the Aegean coast of Greece and a large Adriatic clade from the Venetian Lagoon, the Po River drainage and the Cetina River drainage in Croatia (similar patterns were recovered in P. marmoratus by Mejri et al., 2011 and Vanhove et al., 2012, and in P. minutus by Stefanni \& Thorley, 2003 and Gysels et al., 2004). This Pliocene and Pleistocene diversification could be old enough to be related to the MSC and could even indicate the presence of cryptic species within $P$. marmoratus. Neither intraspecific nor interspecific differentiation in sand gobies is young enough to be correlated with Pleistocene glaciation-induced changes in sea level. Rather, we correlate episodes of diversification among sand gobies with both the Miocene Tethys closure/Paratethys isolation and the dimunition of the Mediterranean during the Miocene/Pliocene MSC. We show that the sand gobies have occupied European waters for much longer than previously assumed and that they have diversified in concert with major tectonic events in the region.

\section{ACKNOWLEDGEMENTS}

We would like to thank C. Anastasiadou, R. Liasko, V. Liousia, V. Georgalas and E. Koutrakis for assistance in fieldwork and species collection. Funding was secured by the board of the Department of Biological Applications and Technology (BET) and the laboratory of Zoology of BET. This study had the support of Fundação para a Ciência e Tecnologia (FCT), through the strategic project UID/MAR/04292/2013 granted to MARE, and the postdoctoral research grant awarded to C. Gkenas (SFRH/BPD/ 84859/2012). We also thank the editor and two anonymous reviewers for comments that improved the manuscript.

\section{REFERENCES}

Agorreta A, San Mauro D, Schliewen U, Van Tassell JL, Kovacic M, Zardoya R, Rüber L. 2013. Molecular phylogenetics of Gobioidei and phylogenetic placement of European gobies. Molecular Phylogenetics and Evolution 69: 619-633. 
Ahnelt H. 1995. Two new species of Knipowitschia Iljin, 1927 (Teleostei: Gobiidae) from Western Anatolia. Mitteilungen aus dem Hamburgischen Zoologischen Museum und Institut 92: $155-168$.

Ahnelt H. 2011. Two new sympatric Knipowitschia species (Teleostei: Gobiidae) from an eastern Mediterranean coastal lake-examples of different dispersal patterns? Zootaxa 3114: 22-30.

Ahnelt H, Bianco PG. 1990. Orsinigobius milleri n. sp., a new species of fresh water goby from W-Greece (Pisces: Gobiidae). Annalen des Naturhistorischen Museums in Wien 91B: 1-6.

Costa FO, Landi M, Martins R, Costa MH, Costa ME, Carneiro M, Alves MJ, Steinke D, Carvalho GR. 2012. A ranking system for reference libraries of DNA barcodes: application to marine fish species from Portugal. PLoS One 7: e35858.

Drummond AJ, Suchard MA, Xie D, Rambaut A. 2012. Bayesian phylogenetics with BEAUti and the BEAST 1.7. Molecular Biology and Evolution 29: 1969-1973.

Duggen S, Hoernle K, van den Bogaard P, Rüpke L, Morgan JP. 2003. Deep roots of the Messinian salinity crisis. Nature 422: 602-606.

Economidis PS, Miller PJ. 1990. Systematics of freshwater gobies from Greece (Teleostei: Gobiidae). Journal of Zoology 221: $125-170$.

Freyhof J. 2011. Diversity and distribution of freshwater gobies from the Mediterranean, the Black and Caspian seas. In: Patzner RA, Van Tassell JL, Kovačić M, Kapoor, BG, eds. The biology of gobies. Enfield, NH: Science Publishers, 279-288.

Froese R, Pauly D, eds. 2017. FishBase. Available at: www. fishbase.org

Geiger MF, Herder F, Monaghan MT, Almada V, Barbieri R, Bariche M, Berrebi P, Bohlen J, Casal-Lopez M, Delmastro GB, Denys GPJ, Dettai A, Doadrio I, Kalogianni E, Kärst H, Kottelat M, Kovačić M, Laporte M, Lorenzoni M, Marčić Z, Özuluğ M, Perdices A, Perea S, Persat H, Porcelotti S, Puzzi C, Robalo J, Šanda R, Schneider M, Šlechtová V, Stoumboudi M, Walter S, Freyhof J. 2014. Spatial heterogeneity in the Mediterranean biodiversity hotspot affects barcoding accuracy of its freshwater fishes. Molecular Ecology Resources 14: 1210-1221.

Gysels ES, Hellemans B, Patarnello T, Volckaert FAM. 2004. Current and historic gene flow of the sand goby Pomatoschistus minutus on the European continental shelf and Mediterranean Sea. Biological Journal of the Linnean Society 83: 561-576.

Hallam A. 1994. An outline of Phanerozoic biogeography. Oxford: Oxford University Press, 246.

Huyse T, Van Houdt J, Volckaert FA. 2004. Paleoclimatic history and vicariant speciation in the "sand goby" group (Gobiidae, Teleostei). Molecular Phylogenetics and Evolution 32: 324-336.

Knebelsberger T, Thiel R. 2014. Identification of gobies (Teleostei: Perciformes: Gobiidae) from the North and Baltic Seas combining morphological analysis and DNA barcoding. Zoological Journal of the Linnean Society 172: 831-845.
Kottelat M, Freyhof J. 2007. A handbook of European freshwater fishes. Cornol, Switzerland: Publications Kottelat, 646.

Kovačić M. 2005. A new species of Knipowitschia (Gobiidae) from Dalmatia, Croatia. Cybium 29: 275-280.

Kovačić M, Pallaoro A. 2003. Is Knipowitschia caucasicalike form from the Adriatic sea a new goby species? Evidence from a morphological approach in the eastern Adriatic sea. Cybium 27: 131-136.

Krijgsman W, Hilgen FJ, Raffi I, Sierro FJ, Wilson DS. 1999. Chronology, causes and progression of the Messinian salinity crisis. Nature 400: 652-655.

Landi M, Dimech M, Arculeo M, Biondo G, Martins R, Carniero M, Carvalho GR, Lo Brutto S, Costa FO. 2014. DNA barcoding for species assignment: the case of Mediterranean marine fishes. PLoS One 9: e106135.

Larmuseau MHD, Huyse T, Vancampenhout K, Van Houdt JKJ, Volckaert FAM. 2010. High molecular diversity in the rhodopsin gene in closely related goby fishes: a role for visual pigments in adaptive speciation? Molecular Phylogenetics and Evolution 55: 689-698.

Levy A, Doadrio I, Almada VC. 2009. Historical biogeography of European leuciscins (Cyprinidae): evaluating the Lago Mare dispersal hypothesis. Journal of Biogeography 36: 55-65.

Malavasi S, Gkenas C, Leonardos I, Torricelli P, Mclennan DA. 2012. The phylogeny of a reduced 'sand goby'group based on behavioural and life history characters. Zoological Journal of the Linnean Society 165: 916-924.

McKay SI, Miller PJ. 1997. The affinities of European sand gobies (Teleostei: Gobiidae). Journal of Natural History 31: 1457-1482.

Mejri R, Arculeo M, Ben Hassime OK, Lo Brutto S. 2011. Genetic architecture of the marbled goby Pomatoschistus marmoratus (Perciformes, Gobiidae) in the Mediterranean Sea. Molecular Phylogenetics and Evolution 58: 395-403.

Miller PJ. 1986. Gobiidae. In: Whitehead PJI, Bauchot ML, Huereau JC, Nielson J, Tortononese E, eds. Fishes of the North-eastern Atlantic and the Mediterranean. Paris: UNESCO, 1019-1085.

Miller PJ. 1990. The endurance of endemism - the Mediterranean fresh-water gobies and their prospects for survival. Journal of Fish Biology 37: 145-156.

Miller PJ. 2004. The freshwater fishes of Europe, Vol 8/II Gobiidae, Germany: AULA-Verlag, Wiebelsheim, 478.

Miller PJ, Šanda R. 2008. A new west Balkanian sand goby (Teleostei: Gobiidae). Journal of Fish Biology 72: 259-270.

Orszag-Sperber, F. 2006. Changing perspectives in the concept of "Lago-Mare" in Mediterranean Late Miocene evolution. Sedimentary Geology 188: 259-277.

Penzo E, Gandolfi G, Bargelloni L, Colombo L, Patarnello T. 1988. Messinian salinity crisis and the origin of freshwater lifestyle in western Mediterranean Gobies. Molecular Biology and Evolution 15: 1472-1480.

Rambaut A. 1999. FigTree 1.3.1. Available at: http://tree.bio. ed.ac.uk/software/figtree/

Rögl F. 1998. Palaeogeographic considerations for Mediterranean and Paratethys Seaways (Oligocene to Miocene). Annalen des Naturhistorischen Museums in Wien 99A: $279-310$. 
Rögl F. 1999a. Mediterranean and Paratethys palaeogeography during the Oligocene and Miocene. In: Agusti J, Rook L, Andrews P, eds. The evolution of Neogene terrestrial ecosystems in Europe. Cambridge University Press, Cambridge, 8-22 pgs.

Rögl F. 1999b. Mediterranean and Paratethys. Facts and hypotheses of an Oligocene to Miocene paleogeography (short overview). Geologica Carpathica 50: 339-349.

Rubinoff D, Holland BS. 2005. Between two extremes: mitochondrial DNA is neither the Panacea nor the Nemesis of phylogenetic and taxonomic inference. Systematic Biology 54: 952-961.

Schliep KP. 2011. Phangorn: phylogenetic analysis in R. Bioinformatics 27: 592-593.

Schwarzhans W, Ahnelt H, Carnevale G, Japundžić S, Bradić K, Bratishko A. 2017. Otoliths in situ from Sarmatian (Middle Miocene) fishes of the Paratethys. Part III: tales from the cradle of the Ponto-Caspian gobies. Swiss Journal of Palaeontology 136: 45-92.

Stefanni S, Thorley JL. 2003. Mitochondrial DNA phylogeography reveals the existence of an evolutionarily significant unit of the sand goby Pomatoschistus minutus in the Adriatic (Eastern Mediterranean). Molecular Phylogenetics and Evolution 28: 601-609.

Thacker CE. 2011. Systematics of Gobiidae. In: Patzner RA, Van Tassell JL, Kovačić M, Kapoor, BG, eds. The biology of gobies. Enfield, NH: Science Publishers, 129-136.

Thacker CE. 2013. Placement of the European sand gobies in Gobionellidae and characterization of gobionellid lineages (Gobiiformes: Gobioidei). Zootaxa 3619: 369-382.
Thacker CE. 2014. Species and shape diversification are inversely correlated among gobies and cardinalfishes (Teleostei: Gobiiformes). Organisms, Diversity, and Evolution 14: $419-436$.

Thacker CE. 2015. Biogeography of goby lineages (Gobiiformes: Gobioidei): origin, invasions and extinction throughout the Cenozoic. Journal of Biogeography 42: 1615-1625.

Thacker CE, Roje DM. 2011. Phylogeny of Gobiidae and identification of gobiid lineages. Systematics and Biodiversity 9: 329-347.

Vanhove MP, Economou AN, Zogaris S, Larmuseau MH, Giakoumi S, Kalogianni E, Volckaert FAM, Huyse T. 2012. Phylogenetics and biogeography of the Balkan 'sand gobies' (Teleostei: Gobiidae): vulnerable species in need of taxonomic revision. Biological Journal of the Linnean Society 105: 73-91.

Vukić J, Kovačić M, Zogaris S, Šanda R. 2016. Rediscovery of Knipowitschia goerneri and its molecular relationships with other European northern Mediterranean Knipowitschia species (Teleostei: Gobiidae). Ichthyological Exploration of Freshwaters 26: 363-372.

Ward RD, Zemlak TS, Innes BH, Last PR, Hebert PD. 2005. DNA barcoding Australia's fish species. Philosophical Transactions of the Royal Society of London B: Biological Sciences 360: 1847-1857.

Zardoya R, Meyer A. 1996. Phylogenetic performance of mitochondrial protein-coding genes in resolving relationships among vertebrates. Molecular Biology and Evolution 13: 933-942.

\section{SUPPORTING INFORMATION}

Additional Supporting Information may be found in the online version of this article at the publisher's web-site.

Table S1. Kimura two parameter genetic distances among sand goby taxa used in BEAST analysis 